\title{
Concomitant Measurement of Fibrinopeptide A and $B$ in Rabbit Plasma using High-Performance Liquid Chromatography
}

\author{
Kiyohiko KINJOH*1, Mariko NAKAMURA*1, Masanori SUNAGAWA*1, \\ Kazuhiko HANASHIRO*1 and Tadayoshi KOSUGI*1,*2
}

家鬼血漿フィブリノペプタイド A および B の HPLC を用いた定量法

金城紀代彦*1 中村真理子*1 砂 川 昌 範*1

花城和彦*1 小杉忠誠*1,*2

Key words : rabbit fibrinopeptides, plasma-precoated C18 column, reverse-phase HPLC

HPLC を用い, 家鬼血漿中フィブリノペプタイド A (FPA) および B (FPB) の同時測定・ 定量法の開発を意図した。 HPLCのカラムには, 逆相 C18 カラムを用いた. 精製家兔フィブリ ノゲンとウシ・トロンビンを用いてフィブリン塊を作製し，その上清より精製した FPA および FPB を用い, 検量線を作成した. $1 \sim 25 \mu \mathrm{g} / \mathrm{m} l$ の範囲で良好な直線関係が得られた。家鬼血漿 中 FPA およびFPB の検出・定量法の検討には，家鬼血漿をあらかじめコーティングした plasma-precoated C18 カラムを用いて，検体の前処理を行った。その結果， $3.1 \sim 12.5 \mu \mathrm{g} / \mathrm{m} l$ の範囲内においては，FPA および FPB の血漿中濃度とピーク高との間に良好な直線関係が得 られ, 回収率は 80〜 100\%であった.しかしながら,血漿中濃度が $25 \mu \mathrm{g} / \mathrm{m} l$ の時には,特に FPB の回収率の低下 $(50 \%)$ が認められた。

本法により，3.1〜 $12.5 \mu \mathrm{g} / \mathrm{m} l$ の範囲内においては，家鬼血漿中 FPA および FPB の同時測 定・定量が可能であることが明らかとなった。しかしながら，血漿中の極微量の FPA および FPB を検出・定量するためには, 更なる高感度化が必要と考えられた.

\begin{abstract}
We developed a method for the isolation and estimation of both fibrinopeptide A (FPA) and fibrinopeptide B (FPB) in rabbit
\end{abstract}

plasma using high-performance liquid chromatography with a C 18 column. On analysis of purified fibrinopeptides in phosphatebuffered saline, a good linear relationship between the height count and concentration

*1 琉球大学医学部生理学第一講座〔广 903-01 沖縄県中頭郡西原町上原 207〕: 1 st Department of Physiology and ${ }^{* 2}$ The Research Center of Comprehensive Medicine, School of Medicine, University of the Ryukyus, 207 Uehara, Nishihara, Okinawa 903-01, Japan.

受付: 1996. 12.7, 受理: 1997.2. 22 . 
of peptides (between 1 and $25 \mu \mathrm{g} / \mathrm{ml}$ ) was observed. On analysis of fibrinopeptides in plasma, which had been prepared with a plasma-precoated C 18 column, FPA and FPB were isolated from the other plasma constituents completely, and a good linear relationship between the height count and concentration of peptides was observed within the range between 3.1 and $12.5 \mu \mathrm{g} /$ $\mathrm{ml} .80 \sim 100 \%$ of the FPA and FPB was recovered within this range. However, at a concentration of $25 \mu \mathrm{g} / \mathrm{m} l$, the recovery values fell to $77 \%$ (FPA) and 50\% (FPB).

\section{Introduction}

During the conversion of fibrinogen to fibrin induced by thrombin, FPA is released initially from the fibrinogen molecules, and FPB is then released consecutively ${ }^{1)-4)}$. We postulate that the FPA released from fibrinogen may regulate the subsequent release of FPB in the early phase of the fibrinogen to fibrin conversion. In addition, it has been suggested that the ratio of released FPA and FPB is an important factor for the formation of fibrin, and FPA may be a key substance in initiating fibrin conversion from fibrinogen. We are attempting to clarify such an hypothesis by experimentation. For this purpose, we devised a method for the simultaneous estimation of FPA and FPB in animal experiments. Concerning the assay of fibrinopeptides in non-human species, radioimmunoassays for canine $\mathrm{FPA}^{5}$, rat $\mathrm{FPA}^{6}$ and guineapig FPA $^{7)}$ have already been developed. We planned to use rabbits as an experimental animal, but practical methods for the measurement of rabbit fibrinopeptides are not available. We therefore initially developed an ELISA method for the assay of rabbit FPA using a monoclonal antibody ${ }^{8}$, and also attempted to devise an assay method for estimating rabbit FPB employing an anti- rabbit FPB monoclonal antibody ${ }^{9}$. However, these immunochemical methods are not capable of estimating both FPA and FPB simultaneously using the same sample; that is, the methods are not suitable for studies on the quantitative relationship between FPA and FPB in the same sample. In recent years, procedures involving high-performance liquid chromatography (HPLC) that simultaneously identify and quantify both FPA and FBA, while demonstating rapidity and high sensitivity, have been developed for assaying fibrinopeptides released from bovine ${ }^{10)}$ and human fibrinogens ${ }^{1112)}$. On this basis, we devised a procedure for estimating rabbit FPA and FPB simultaneously employing the HPLC procedure.

\section{Materials and Methods}

\section{Reagents.}

Rabbit fibrinogen was purified according to the technique of Doolittle et al. ${ }^{13)}$. Bovine thrombin was purchased from Mochida Pharmaceutical Co. (Tokyo, Japan). Purified rabbit FPA and FPB were prepared by column chromatography on Dowex 50W-X2 following the procedure of Blombäck et al. ${ }^{214)}$, as described previously ${ }^{8}$. Acetonitrile and methanol of HPLC grade were purchased from Nacalai Tesque, Inc. (Kyoto, Japan). Wakogel PL-40C18, reverse phase C 18 silica gel (particle size : $40 \mu \mathrm{m}$ ), was purchased from Wako Pure Chemical Industries, Ltd. (Tokyo, Japan). Corning 25801, polystyrene microtiter plate, was purchased from Corning Inc. (N.Y., U.S.A) $0.22 \mu \mathrm{m}$ Millex-GV filters and $0.45 \mu \mathrm{m}$ Millex-HV filters were purchased from Millipore Co. (Bedford, MA, U.S.A.). Unless otherwise stated, only reagent-grade chemicals were employed as other reagents.

Water used in the present experiments was purified according to Sampson ${ }^{15)}$ and Rabel ${ }^{16)}$; 
i.e. $5 \mathrm{~m} l$ of Wakogel PL-40C18 suspended in methanol was packed into a column $(2.0 \times 10$ $\mathrm{cm}$ ), washed with $10 \mathrm{~m} l$ of methanol, $10 \mathrm{~m} l$ of distilled water, then $10 \mathrm{~m} l$ of acetonitrile was followed by about $50 \mathrm{~m} l$ of distilled water. About $2 l$ of Milli-Q system reagent water was passed through this $\mathrm{C} 18$ column, and then filtered using a $0.45 \mu \mathrm{m}$ Millex-HV filter.

\section{HPLC}

Analytical HPLC was performed with a Hitachi high-performance liquid chromatograph equipped with a Model L-6210 intelligent pump connected to a Model L-6010 pump, a Model AS-4000 intelligent auto-sampler, a Model D-2500 chromato-integrator, and a Model L-4000 UV-detector, all from Hitachi Ltd. (Tokyo, Japan). The column employed for all analyses was a reverse phase C 18 column $(4 \mathrm{~mm}$ i.d. $\times 15 \mathrm{~cm}$ ) packed with Hitachi Gel \# 3056 (particle size : $5 \mu \mathrm{m}$ ), also from Hitachi Ltd. The solvents used for chromatography were $0.1 \%$ phosphoric acid (solvent A) and 70\% acetonitrile/ $0.1 \%$ phosphoric acid (solvent B). Gradient elution was achieved as follows: the initial acetonitrile concentration of $10 \%(86 \% \mathrm{~A}$, $14 \% \mathrm{~B}$ ) was programmed to increase to $30 \%$ $(57 \%$ A, $43 \%$ B) over a period of $10 \mathrm{~min}$ after sample application, and then to increase from $30 \%$ to $35 \%(50 \% \mathrm{~A}, 50 \% \mathrm{~B})$ over the following $20 \mathrm{~min}$. The flow rate was $0.5 \mathrm{ml} /$ min. Peptide materials were monitored at 210 $\mathrm{nm}$. After each elution, the column was washed with $70 \%$ acetonitrile $(0 \%$ A, $100 \%$ B) for about $15 \mathrm{~min}$ and then re-equilibrated with $10 \%$ acetonitrile as described above.

Preparation of fibrin clot supernatant for isolation of fibrinopeptides.

The supernatant of fibrin clots for the isolation of fibrinopeptides was prepared according to the method described previous$1 \mathrm{y}^{8)}$ with some modifications. $0.1 \mathrm{~g}$ of rabbit fibrinogen was dissolved in $10 \mathrm{~m} l$ of $0.15 \mathrm{M}$ ammonium acetate, $\mathrm{pH} 7.0 .1 \mathrm{~m} l$ of bovine thrombin ( 3.9 units $/ \mathrm{m} l$ ) was then added and the mixture incubated at $37^{\circ} \mathrm{C}$ for 6 hours. After incubation, the clot was crushed and removed. Since the supernatant of the clot was no longer clotted by additional thrombin, $100 \%$ of rabbit fibrinogen proved to be converted to fibrin. The supernatant was pooled, deproteinized with $70 \%$ acetonitrile as the final concentration, then centrifuged at 3000 r.p.m. for $15 \mathrm{~min}$ at $4^{\circ} \mathrm{C}$. The supernatant was passed through a $0.22 \mu \mathrm{m}$ MillexGV filter, and lyophilized. The resultant material was dissolved in water and subjected to HPLC analysis. The concentrations of fibrinopeptides were determined by the FolinLowry procedure ${ }^{17)}$.

Monoclonal antibodies against rabbit FPA and FPB.

Monoclonal antibody against rabbit FPA was generated and purified as described previously ${ }^{8}$, and that against rabbit $\mathrm{FPB}$, also as described previously ${ }^{9)}$.

Determination of FPA and FPB by ELISA.

The coating of rabbit fibrinopeptides onto the polystyrene microtiter plate was carried out by coupling to a polylysine coated plate with glutaraldehyde, as described previous$1 y^{8}$. After blocking with $1 \%$ gelatin, the additions of anti-FPA monoclonal antibody and anti-FPB monoclonal antibody were made to each well. The procedure followed was similar to that described previously ${ }^{8}$.

Preparation of plasma-precoated C18 column.

About $5 \mathrm{ml}$ of Wakogel PL-40C18 suspended in methanol was packed into a column 
$(1.2 \times 5.5 \mathrm{~cm})$, and washed with $10 \mathrm{~m} l$ of methanol followed by $10 \mathrm{~m} l$ of D-PBS. $2 \mathrm{~m} l$ of rabbit plasma was diluted with $18 \mathrm{ml}$ of D-PBS and applied to the column, which was then washed with D-PBS. This process of plasma-coating was repeated again. $0.5 \mathrm{ml}$ of the resultant plasma-precoated $\mathrm{C} 18$ gel was packed into a column $(0.9 \times 5 \mathrm{~cm})$ and washed with methanol, $0.1 \%$ phosphoric acid, $35 \%$ acetonitrile in $0.1 \%$ phosphoric acid, $100 \%$ acetonitrile and methanol followed by $0.1 \%$ phosphoric acid. The column was then used for the subsequent experiments.

Preparation of plasma-fibrinopeptides mixture for HPLC analysis.

For deproteinization of plasma samples containing rabbit fibrinopeptides, and also for trapping fibrinopeptides, the plasmafibrinopeptides mixture was prepared by one of two procedures as described below. In the first procedure, a plasma-fibrinopeptides mixture was prepared following the method of Leeksma et al. ${ }^{18)}$. As such, $500 \mu l$ of a mixture of rabbit plasma and fibrinopeptides was precipitated with $50 \%$ ethanol and subjected to heat-treatment in boiling water. 0.5 $\mathrm{m} l$ of Wakogel PL-40C18 suspended in methanol was packed into a column $(0.9 \times 5$ $\mathrm{cm}$ ), and washed with $5 \mathrm{~m} l$ of methanol and $5 \mathrm{~m} l$ of $0.1 \%$ phosphoric acid before addition of the samples. The prepared sample was diluted with $9 \mathrm{~m} l$ of $0.1 \%$ phosphoric acid, and applied to the $\mathrm{C} 18$ column. After washing with $5 \mathrm{~m} l$ of $0.1 \%$ phosphoric acid, the peptide materials were eluted with $35 \%$ acetonitrile in $0.1 \%$ phosphoric acid. The initial $2 \mathrm{~m} l$ of eluate was pooled, and $50 \mu l$ of this eluate was analyzed by HPLC.

In the second procedure, the plasmafibrinopeptides mixture was prepared using plasma-precoated C 18 columns. $500 \mu l$ of a plasma-fibrinopeptides mixture was diluted

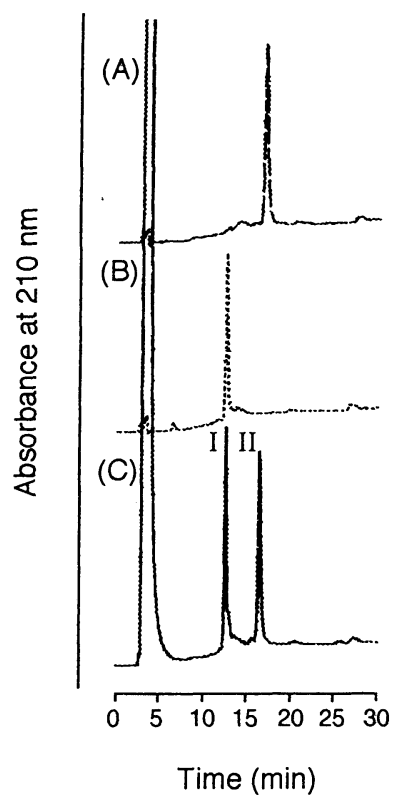

Fig. 1 HPLC elution patterns of rabbit fibrinopeptides.

(A) : Rabbit FPA purified by Dowex 50W-X2 ion-exchange chromatography. (B) : Rabbit FPB purified by Dowex 50W-X2 ion-exchange chromatography. (C) : Fibrinopeptides in supernatant of fibrin clot after deproteinization.

with $0.1 \%$ phosphoric acid, and then applied to a plasma-precoated C 18 column which had been washed with methanol and $0.1 \%$ phosphoric acid. The peptide materials were eluted with $35 \%$ acetonitrile, and $50 \mu l$ of the eluate was subjected to HPLC analysis as described above.

\section{Results}

HPLC of rabbit fibrinopeptides.

Chromatograms of purified rabbit fibrinopeptides and of the peptides in the supernatant of a fibrin clot are shown in Fig. 1. On analysis of the supernatant of the fibrin clot, two peaks (labeled I and II, respectively) were separated after the first peak due to solvents and salts in the applied sample (Fig. 1C). The retention times of peak I and peak 
(A)

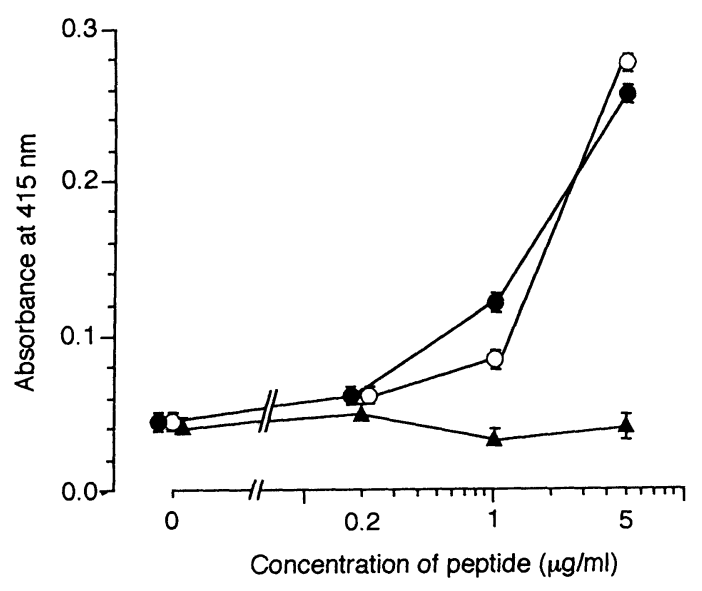

(B)

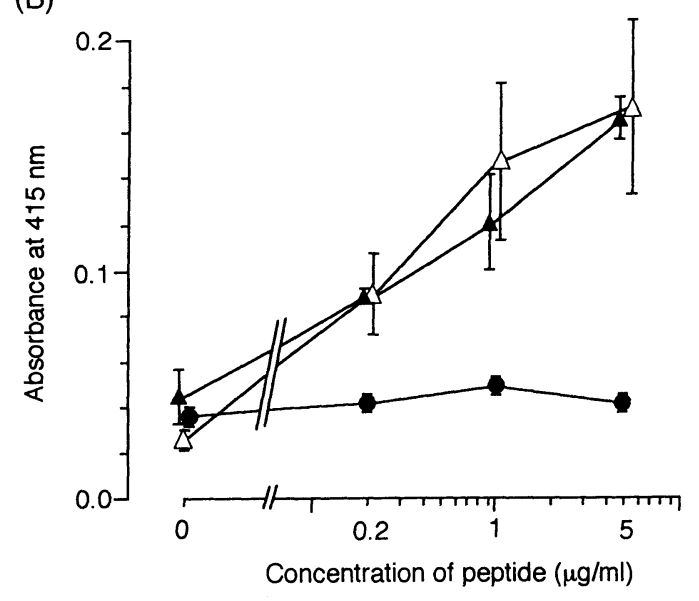

Fig. 2 Reactions of anti-FPA and anti-FPB monoclonal antibodies against peak I peptide and peak II peptide. The reactions of anti-FPA monoclonal antibody against purified FPA $(O)$, peak I peptide $(\mathbf{\Lambda})$, and peak II peptide $(\mathbf{O})$ are shown in (A). The reactions of anti-FPB monoclonal antibody against purified FPB $(\triangle)$, peak I peptide $(\boldsymbol{\Delta})$, and peak II peptide $(\mathbf{O})$ are shown in (B). Results are expressed as mean values of 2 experiments.

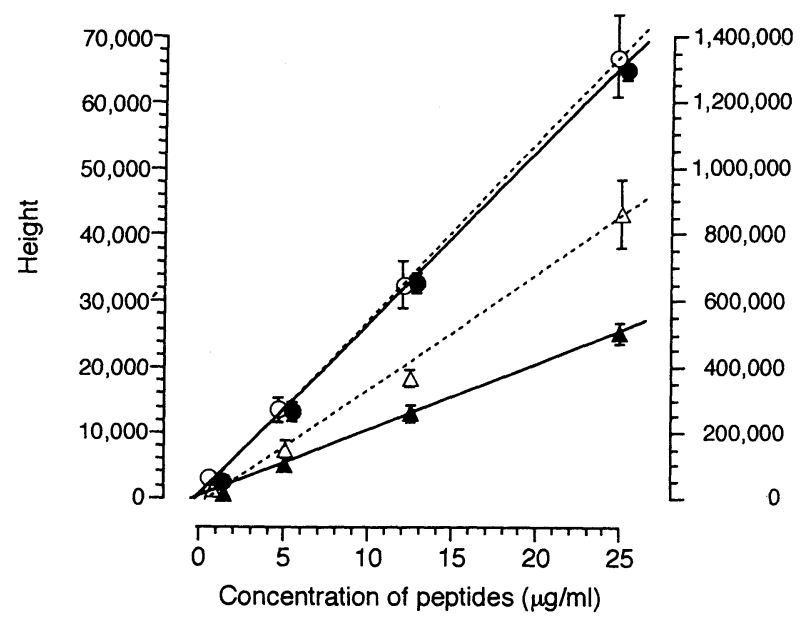

Fig. 3 Correlation of the concentrations of fibrinopeptides with the counts of height/area of peptide peaks on the chromatograms. The height counts of FPA ( $\mathbf{\Delta})$ and FPB $(\boldsymbol{O})$, and the area counts of FPB $(\triangle)$ and FPB $(O)$ are shown. Results are expressed as means \pm S.D. $(n=4)$. 
II corresponded to those of purified FPB and FPA, respectively (Fig. $1 \mathrm{~A}$ and $\mathrm{B}$ ).

\section{Reactions of anti-FPA and anti-FPB monoclonal antibodies.}

Eluates of peak I and peak II were diluted with Dulbecco's PBS and coated onto polystyrene microtiter plates, respectively. AntiFPA monoclonal antibody demonstrated a positive reaction against the peak II peptide and purified FPA (Fig. 2A). Anti-FPB monoclonal antibody demonstrated a positive reaction against the peak I peptide and purified FPB (Fig. 2B). Based on these results, peak I was identified as FPB, and peak II as FPA.

Correlation of fibrinopeptides concentrations with counts of height and area of the peptide peak on chromatograms.

Counts of the height and/or area of the peptide peak were calculated with a Model D2500 chromato-integrator. On analysis of the FPA in the range between 1 and $25 \mu \mathrm{g} / \mathrm{ml}$, a good linear relationship between the FPA concentration and count of the height was observed, as well as between the FPA concentration and count of the area of the peptide peak (Fig. 3). On analysis of the FPB within the same range as the FPA, a good linear relationship was again demonstrated. In both cases, the standard deviation was greater in terms of the area counts than in those of the height counts. The calibration curve for determination of the FPA and FPB concentrations was therefore constructed using the data for height counts.

Estimation of fibrinopeptides in plasma prepared by ethanol precipitation and heattreatment.

The plasma-fibrinopeptides mixture prepared according to the procedure of Leeksma et al. as described above, was subjected to
Table 1 Recovery of the fibrinopeptides by sample preparation according to the procedure of Leeksma et al.

\begin{tabular}{ccc}
\hline Sample & $\begin{array}{c}\text { Concentration of peptide } \\
(\mu \mathrm{g} / \mathrm{ml})\end{array}$ & $\begin{array}{c}\text { Recovery* } \\
(\%)\end{array}$ \\
\hline FPA in PBS & 3.13 & $100.7 \pm 13.0$ \\
& 6.25 & $101.3 \pm 9.1$ \\
FPA in plasma & 12.5 & $116.1 \pm 4.7$ \\
& 25 & $118.1 \pm 7.9$ \\
FPB in PBS & 3.13 & $81.9 \pm 9.7$ \\
& 6.25 & $97.5 \pm 13.8$ \\
& 12.5 & $95.4 \pm 7.2$ \\
& 25 & $94.4 \pm 1.9$ \\
FPB in plasma & 6.13 & $79.6 \pm 9.0$ \\
& 12.5 & $67.6 \pm 3.1$ \\
& 25 & $81.9 \pm 16.3$ \\
& 3.13 & $94.6 \pm 18.8$ \\
& 6.25 & $56.5 \pm 6.9$ \\
& 12.5 & $64.3 \pm 11.7$ \\
& 25 & $76.0 \pm 8.2$ \\
\hline
\end{tabular}

*) Means \pm S.D. $(n=3)$

HPLC analysis. Although a good linear relationship was observed on HPLC analysis of both the FPA and FPB, the regression line of each peptide in the plasma did not correspond to that of each peptide in PBS (data not shown). The recovery value of FPA in the plasma was $80-100 \%$, whereas that of FPB in the plasma was no more than $50 \sim 80 \%$ (Table 1). As a result, this procedure appeared to be inappropriate for the measurement of rabbit fibrinopeptides, especially FPB, in the plasma.

Estimation of fibrinopeptides in plasma prepared with plasma-precoated C18 columns.

Initially we prepared a plasma-FPA mixture using an intact $\mathrm{C} 18$ column as described above, and subjected this to HPLC analysis. However, as an unidentified broad peak overlap with FPB was observed (Fig. 4C), this procedure was deemed inappropriate for the plasma preparation to quantify rabbit FPB. Therefore, we prepared plasma-fibrinopeptides mixtures using a plasma-precoated $\mathrm{C}$ 


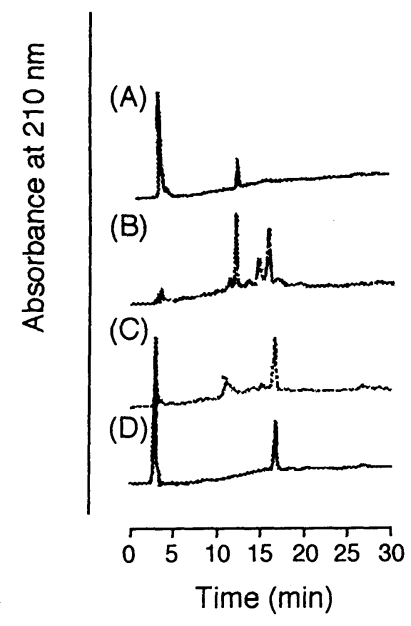

Fig. 4 HPLC elution patterns of prepared plasma-fibrinopeptides mixtures. The plasma-fibrinopeptides mixture was prepared using a plasma-precoated C 18 column (B), and the plasma-FPA mixture was prepared using an intact C 18 column (C); the chromatograms of purified FPB (A) and purified FPA

(D) are shown as controls.

18 column as described above. Consequently, the FPA and FPB in the rabbit plasma separated completely, and overlap due to plasma constituents was not observed with any peaks. Clear peak separation was observed in the chromatograms irrespective of the concentration of fibrinopeptides (Fig. 4B).

On analysis of the FPA in plasma, a good linear relationship was obtained, and the regression line of FPA in the plasma corresponded to that in PBS (Fig. 5A). On analysis of FPB below $12.5 \mu \mathrm{g} / \mathrm{m} l$ in plasma, a good linear relationship was obtained, but the height counts were consistently lower than those of FPB in PBS (Fig. 5A). Within this range, the recovery of $\mathrm{FPB}$ was $80 \sim 90 \%$ (Fig. 5B).

Plasma-fibrinopeptides mixture containing $25 \mu \mathrm{g} / \mathrm{m} l$ of FPA and FPB was then diluted with PBS. $500 \mu l$ of the diluted mixtures was mixed with $4.5 \mathrm{~m} l$ of $0.1 \%$ phosphoric acid and prepared using plasma-precoated $\mathrm{C} 18$
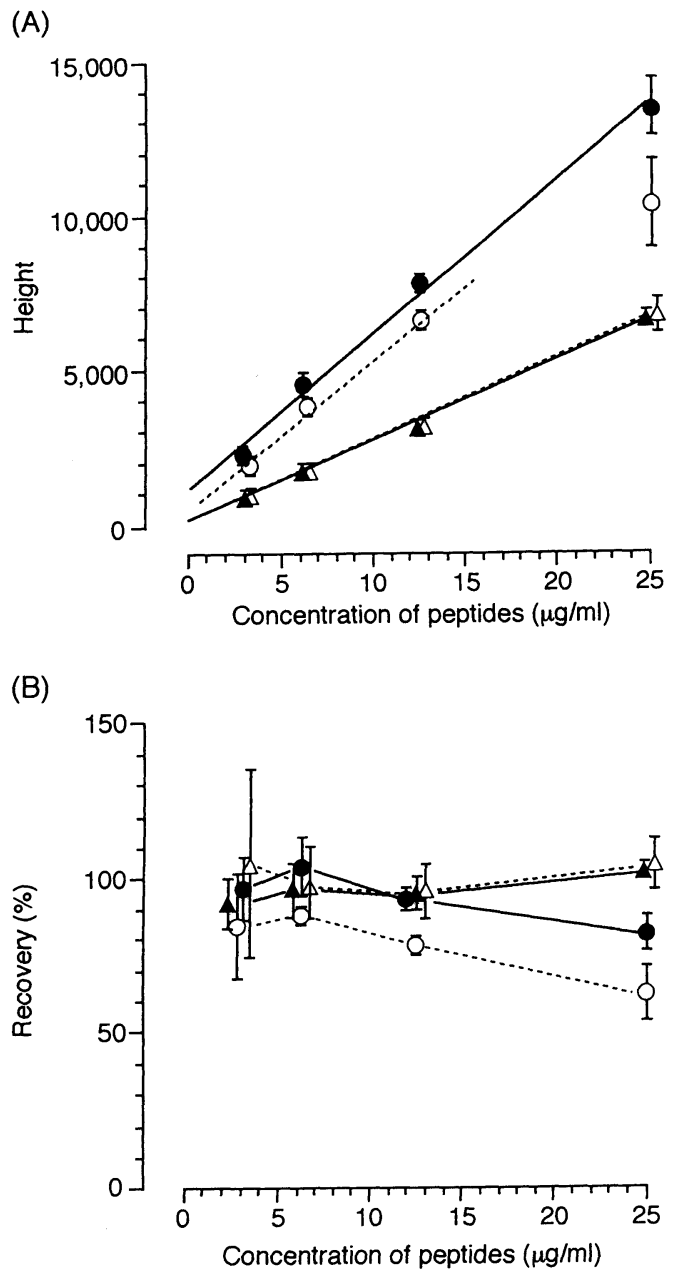

Fig. 5 Plasma-fibrinopeptides mixtures were prepared using a plasmaprecoated C 18 column. The correlation between the concentrations of fibrinopeptides and height counts of peptide peaks is shown in (A), and the recoveries of fibrinopeptides are shown in (B). $\triangle$ :FPA in PBS, $\triangle$ : FPA in plasma, :FPB in PBS, and $O$ : FPB in plasma. Results are expressed as means \pm S.D. $(n=3)$.

columns. On HPLC analysis of the resultant samples, $90 \sim 100 \%$ of the FPA was recovered, whereas FPB showed a lower recovery, in which the highest recovery was noted when the sample was diluted at a ratio of $1: 4$ (Fig. 6).

Subsequently, $500 \mu l$ of plasma-fibrino- 


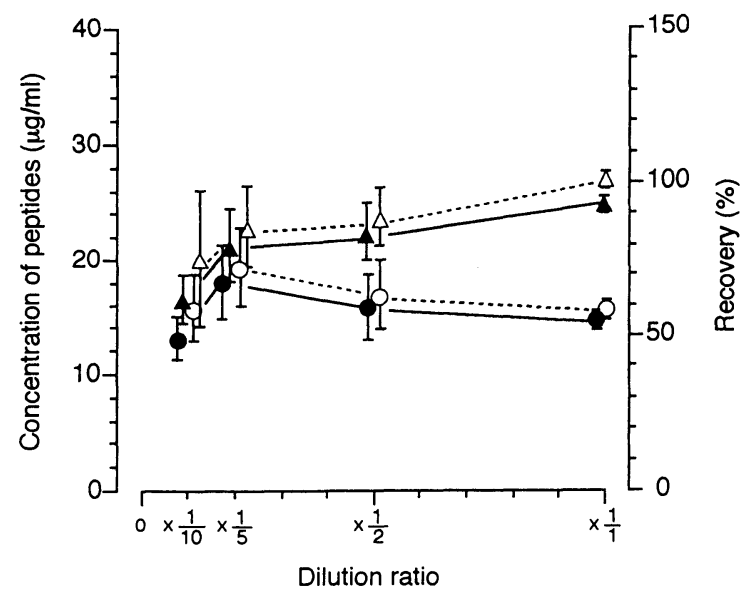

Fig. 6 Effects of dilution of plasmafibrinopeptides mixtures on the concentrations and recoveries of $\mathrm{fi}$ brinopeptides. The concentrations of FPA ( $\Delta$ ) and FPB (O), and the recoveries of FPA $(\triangle)$ and FPB $(O)$ are shown. Results are expressed as means \pm S.D. $(n=3)$.

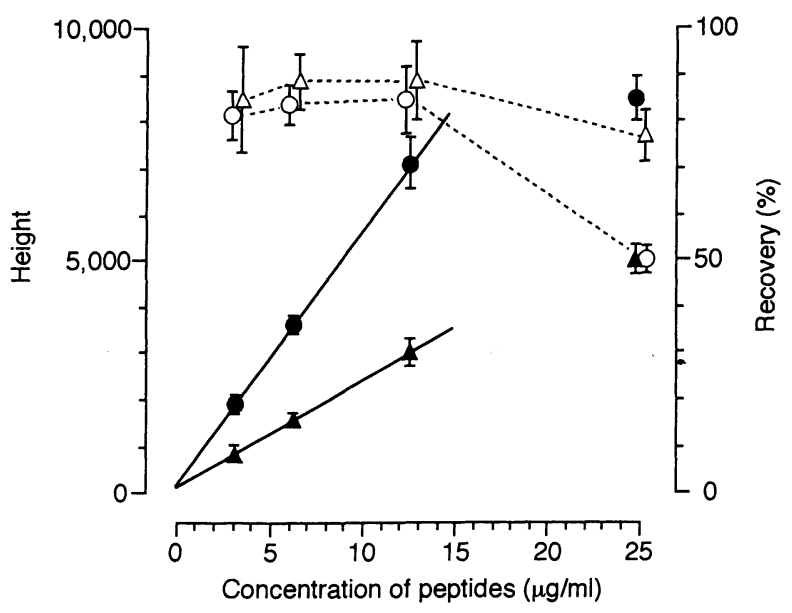

Fig. 7 Correlation of the concentrations of fibrinopeptides with the height counts or recoveries of each fibrinopeptide in plasma. The height counts of FPA $(\boldsymbol{\Delta})$ and FPB (O), and the recoveries of FPA $(\triangle)$ and FPB (O) are shown. Results are experssed as means \pm S.D. $(n=3)$.

peptides mixture was diluted with $2 \mathrm{ml}$ of PBS, mixed with $7.5 \mathrm{~m} l$ of $0.1 \%$ phosphoric acid, and prepared using plasma-precoated C 18 columns. On analysis of the resultant samples, $80 \sim 100 \%$ of the FPA and FPB was recovered within the range between 3.1 and $12.5 \mu \mathrm{g} / \mathrm{ml}$, and no appreciable difference between the recoveries of FPA and FPB was observed. However, at a concentration of 25 $\mu \mathrm{g} / \mathrm{m} l$, the recovery values fell to $77 \%$ (FPA) and 50\% (FPB) (Fig. 7).

\section{Discussion}

We confirmed that the amino acid sequences of rabbit FPA and FPB as reported by Blombäck et al. ${ }^{19)}$, are identical to the sequences of fibrinopeptides isolating by the HPLC method described herein (data not shown). The FPA sequence was determined to be VDPGESTFIDEGATGR (16 residues; molecular weight:1651), and that of FPB, ADDYDDEVLPDAR (13 residues; molecular weight : 1494). The present study demonstrates that the HPLC system with a reversephase $\mathrm{C} 18$ column is a useful tool for isolating and quantifying rabbit fibrinopeptides in the supernatant of fibrin clots. Further, based on the finding that the presence of $50 \%$ ethanol did not elicit any changes in retention time and height count of each fibrinopeptide peak (data not shown), it was proven that this procedure can identify and quantify both 
FPA and FPB simultaneously in the reactants of fibrinogen and thrombin, or thrombin-like enzymes, following $50 \%$ ethanol precipitation.

As a first step in HPLC analysis of plasma samples, sample preparation, such as deproteinization or solvent extraction, is needed for preventing the deterioration of the reverse-phase partition columns ${ }^{16)}$. Initially we prepared plasma samples according to the procedure of Leeksma et al. ${ }^{18)}$. However, this method was inappropriate for recovering rabbit FPA and FPB added to plasma. For samples prepared in the plasma-precoated C 18 columns by application of plasma samples diluted only with PBS and not acidified with $0.1 \%$ phosphoric acid, the recoveries of rabbit fibrinopeptides, especially FPB, was decreased (data not shown). Therefore, we suspect that rabbit fibrinopeptides, especially $\mathrm{FPB}$, bind to plasma proteins in neutral $\mathrm{pH}$. They might be extracted with proteins by ethanol precipitation, but the capture of fibrinopeptides in plasma-precoated C 18 gel would be reduced due to the decrease in free peptides in plasma samples. Hence, the fibrinopeptides recovery yield might be poor.

On HPLC analysis of plasma samples prepared by this procedure, the working range was found to be limited between $3.1 \mu \mathrm{g} / \mathrm{ml}$ and $12.5 \mu \mathrm{g} / \mathrm{ml}$, which is insufficient to detect rabbit fibrinopeptides in the circulating blood. Comparing immunological methods, the working range of our ELISA method for rabbit FPA lies between 0.2 and $25.0 \mu \mathrm{g} / \mathrm{m} l^{8}$, and in the radioimmunoassay of canine FPA, levels ranging from 0.2 to 5.0 pmols can be detected ${ }^{5}$. Clearly, the sensitivity of the HPLC procedure is inferior to that of immunological methods. There is thus a need to improve the analytical procedure described in this paper for estimating rabbit fibrinopeptides at sub-microgram levels. In recent years, microbore column chromatography has become a fundamental technique for the isolation of low-microgram quantities of proteins and peptides, especially for amino acid sequence analysis ${ }^{20)}$. This method has provided an enhanced sensitivity of peptide detection, ranging between 10 and $50 \mathrm{ng}^{20)}$. The technique may also be useful for estimating rabbit fibrinopeptides at such small quantity levels.

\section{References}

1) Bettelheim FR: The clotting of fibrinogen. II. Fractionation of peptide material liberated. Biochim Biophys Acta 19 : 121-130, 1956.

2) Blombäck B, Vestermark A : Isolation of fibrinopeptides by chromatography. Arkiv Kemi $12: 173$ $-182,1958$.

3) Bilezikian SB, Nossel HL, Butler VP Jr, Canfield $\mathrm{RE}$ : Radioimmunoassay of human fibrinopeptide $B$ and kinetics of fibrinopeptide cleavage by different enzymes. J Clin Invest 56 : 438-445, 1975.

4) Blombäck B, Hessel B, Hogg D, Therkildsen L: A two step fibrinogen-fibrin transition in blood coagulation. Nature 275 : 501-505, 1978.

5) Wilner GD, Birken S:Synthesis and radioimmunoassay of canine fibrinopeptide A. Thromb Res 7 : 753-763, 1975.

6) Drummond O, McLaughlin LF, MacGregor LR : Development of a radioimmunoassay for rat fibrinopeptide A. Br J Haematol 77 (Suppl. 1) : 59, 1991.

7) Chen JP, Marsh LC, Schroeder EC : Haemostatic derangements associated with arenavirus infection in the guinea-pig : radioimmunoassay of fibrinopeptide $\mathrm{A}$ to assess thrombin action in infected animals. Blood Coagul Fibrinolysis $4: 165$ $-172,1993$.

8) Kinjoh K, Nakamura M, Kosugi $T$ : Application of a monoclonal antibody to estimate rabbit fibrinopeptide A released by habutobin. Toxicon 32 : 1413-1423, 1994.

9) Kinjoh K, Nakamura M, Kosugi T : Production of a monoclonal antibody against rabbit fi- 
brinopeptide B (FPB) for immunological assay of rabbit FPB. Jpn J Physiol 44 (Suppl. 1) : S117, 1994.

10) Martinelli RA, Scheraga HA : Assay of bovine fibrinopeptides by high-performance liquid chromatography. Anal Biochem $96: 246$ - 249, 1979.

11) Koehn JA, Canfield RE: Purification of human fibrinopeptides by high-performance liquid chromatography. Anal Biochem 116:346-356, 1981.

12) Kehl M, Lottspeich F, Henschen A : Analysis of human fibrinopeptides by high-performance liquid chromatography. Hoppe-Seyler's $Z$ Physiol Chem 362 : 1661-1664, 1981.

13) Doolittle RF, Schubert D, Schwartz SA:Amino acid sequence studies on artiodactyl fibrinopeptides. I. Dromedary camel, mule, deer and cape buffalo. Arch Biochem Biophys 118:456-467, 1967.

14) Blombäck B, Boström $H$, Vestermark $A$ : On the $\left.{ }^{35} \mathrm{~S}\right]$ sulphate incorporation in fibrinopeptide $\mathrm{B}$ from rabbit fibrinogen. Biochim Biophys Acta
$38:$ 502-512, 1960.

15) Sampson RL: High purity water for liquid chromatography. Am Lab 9 : 109-113, 1977.

16) Rabel FM. Use and maintenance of microparticle high-performance liquid chromatography columns. J Chromatogr Sci $18: 394-408,1980$.

17) Lowry OH, Rosenbrough NJ, Farr AL, Randall $\mathrm{RJ}$ : Protein measurement with the Folin-phenol reagent. J Biol Chem 193 : 265-275, 1951.

18) Leeksma OC, Meijer-Huizinga $F$, Stoepman-van Dalen EA, van Ginkel CJW, van Aken WG, van Mourik JA : Fibrinopeptide A and the phosphate content of fibrinogen in venous thromboembolism and disseminated intravascular coagulation. Blood 67 : 1460-1467, 1986.

19) Blombäck B, Blombäck $M$, Grödahl NJ. : Studies on fibrinopeptides from mammals. Acta Chem Scand 19 : 1789-1791, 1965.

20) Simpson RJ, Moritz RL, Begg GS, Rubira MR, Nice EC. : Micropreparative procedures for high sensitivity sequencing of peptides and proteins. Anal Biochem 177 : 221-236, 1989. 